University of Miami Law School University of Miami School of Law Institutional Repository

1977

\title{
Escape From Liberalism: Fact and Value in Karl Llewellyn
}

Kenneth M. Casebeer

University of Miami School of Law, casebeer@law.miami.edu

Follow this and additional works at: https://repository.law.miami.edu/fac_articles

Part of the Legal History Commons

\section{Recommended Citation}

Kenneth M. Casebeer, Escape From Liberalism: Fact and Value in Karl Llewellyn, 1977 Duke L.J. 671 (1977).

This Article is brought to you for free and open access by the Faculty and Deans at University of Miami School of Law Institutional Repository. It has been accepted for inclusion in Articles by an authorized administrator of University of Miami School of Law Institutional Repository. For more information, please contact library@law.miami.edu. 


\title{
ESCAPE FROM LIBERALISM: FACT AND VALUE IN KARL LLEWELLYN
}

\author{
Kenneth M. Casebeer* \\ "Truth," said a traveller, \\ "Is a rock, a mighty fortress; \\ Often have I been to it, \\ Even to its highest tower, \\ From whence the world looks black." \\ "Truth," said a traveller, \\ "Is a breath, a wind, \\ A shadow, a phantom; \\ Long have I pursued it, \\ But never have I touched \\ The hem of its garment." \\ And I believed the second traveller; \\ For truth was to me \\ A breath, a wind, \\ A shadow, a phantom, \\ And never had I touched \\ The hem of its garment. ${ }^{1}$
}

For a legal realist in the 1930's battling the already crumbling orthodoxy of formalism, ${ }^{2}$ the trick in understanding realist poet Stephen Crane

* Assistant Professor of Law, University of Miami School of Law; A.B. Georgetown University, 1971; J.D. Harvard Law School, 1974. Research support is gratefully acknowledged from the Kennedy Institute, Center for Bioethics, Georgetown University. The author wishes to express particular appreciation for encouragement and criticism to Laurence $\mathrm{H}$. Tribe and Roberto M. Unger of the Harvard Law School, and Dean Soia Mentschikoff of the University of Miami School of Law. Their ideas pervade every page and are incapable of complete acknowledgement in footnote.

THE FOLLOWING CITATIONS WILL BE USED IN THIS ARTICLE:

K. Llewellyn, The Bramble Bush: Some Lectures on LaW and Its Study (1930) [hereinafter cited as THE BRAMBLE BuSH];

K. Llewellyn, the COMmon Law Tradition (1960) [hereinafter cited as The Common LAW TRADITION];

W. Twining, Karl Llewellyn and the Realist Movement (1973) [hereinafter cited as TWINING];

Fuller, American Legal Realism, 82 U. PA. L. REv. 429 (1934) [hereinafter cited as Fuller];

Llewellyn, A Realistic Jurisprudence-The Next Step, 30 Colum. L. Rev. 431 (1930) [hereinafter cited as $A$ Realistic Jurisprudence];

Llewellyn, Some Realism About Realism-Responding to Dean Pound, 44 Harv. L. Rev. 1222 (1931) [hereinafter cited as Some Realism About Realism].

1. S. Crane, The Collected Poems of Stephen Crane 30 (W. Follett, ed. 1930).

2. Formalism may be briefly defined as that jurisprudential doctrine which considers every dispute to be susceptible to a single, correct solution, yielding a precedent which can be 
consisted in agreeing with the second traveller without feeling limited by his belief. The realists saw the high degree of abstraction and integration of formalism as a hollow, shelled fortress. Its philosophic completeness, wedded to the classical liberalism of political science (and earlier, economics) served as a tool for the maintenance of existing distributions of wealth and power; its formal "truths" rolled over the rich particularities of life in motion.

One of these legal second travellers, Karl Nickerson Llewellyn, devoted much of his early work to demonstrating the real yet phantom nature of legal doctrine and the impossibility of its singular "truth," at least in any static or given form. Llewellyn typified the realists' focus on the facts of law in action: the results of law suits; the impact of law in cutting short disputes or channeling private conduct; the pervasive influence of prior normative doctrine and societal attitudes in all the law's activities. ${ }^{3}$ This emphasis on the contingent nature of law in a changing society quickly found adherents within a profession no longer able to generate agreement that each legal problem yielded a single correct solution. However, while in the 1930's the increasingly clear inadequacies of formalism's deductive method assured acceptance of the realists' critique, their success turned bittersweet. To many critics, Llewellyn's seeming lack of an alternative normative foundation or process made the destruction of formalism seem almost nihilistic. Of what value could all the relevant data possibly be without an Ought, a Truth to harness to the facts?

It is at this point that this Article intervenes in the old controversy. It will examine the fact-value distinction in Llewellyn's writing to determine the correctness of the anti-realists' charge that the lack of a normative component renders his writings either incoherent or trivial. Examination of this distinction will lead to the following conclusions: (1) Llewellyn has been almost universally and grossly misunderstood; (2) this confusion stems from an epistemological misunderstanding of the requirements of the liberal Is-Ought distinction; ${ }^{4}$ (3) correctly viewed, the fact-value dichotomy is

aggregated with other precedents in an increasingly abstract synthesis. These precedents allow one to clearly mark the boundaries of the private and public spheres, and in addition to define just relations among individuals. From such principles, one may deduce the governing law of any particular case. It is beyond the scope of this Article to argue the historical and theoretical reasons for the collapse of formalism as a viable jurisprudential theory.

3. The major points of departure for the early realist thinkers are traced in TwINING 41-83.

Llewellyn clearly expressed the view that realism was not represented by a school of thinkers who agreed on basic premises. See Some Realism About Realism. However, for purposes of examining the "fact-value" distinction, the grouping creates little distortion. When others criticized the normative deficiencies of realist theory, they almost invariably aimed at Llewellyn. Thus, the defense of Llewellyn, if successful, can for the most part be generalized to cover realist methodology as a whole.

4. As used in this Article, the term "liberal" refers to the dominant social and political philosophy of modern Western democratic societies. The Is-Ought distinction derives from the 
nonexistent; a synthetic, conventional concept which has previously been perceived to be real, thus obscuring useful criticism of the legal system; (4) Llewellyn, perhaps unconsciously, came very close to breaking through this barrier, and much of his work makes little sense if otherwise explained.

Such an examination is important because modern legal theory depends on a separation of legal functions and roles dictated not by a comprehensive and integrated system similar to the formalism demolished by the realists and others, but by the inability of contemporary jurisprudence to generate a replacement. Given the perceived "impossibility" of defining an objective norm with which to criticize substantive theory, the result of the liberalrealist controversy has been an elevation of legal process as the only facet of the law appropriate for thorough investigation. ${ }^{5}$ It has come to be believed that all substantive or "political" decisions can be legitimately made only by a representative legislative body. The resulting call for judicial deferral to the legislature in matters of substantive social policy perpetuates the myth that inaction is a neutral activity, ${ }^{6}$ notwithstanding that every judicial decision of necessity affects wealth or power, through either their maintenance or their redistribution. Llewellyn's goal of identifying all contributing factors in the judicial process is an essential first step toward a new normative focus for all legal institutions to replace the modern dogma of judicial method, which is acritically activist when deferring to the legislative branch and ultimately incoherent in its remaining attempts at intervention in society.

\section{LLEWELlyn: The BASIC CONCEPTS}

Karl Llewellyn saw extreme danger in the formalistic judicial reasoning which dominated lawsuits in the early twentieth century-reasoning which utilized precedents and statutes origmating in a different economic era to determine, apparently automatically, disputes of a totally different nature. The phenomenon of appellate courts declaring the law to be different from widely held lay and academic interpretations prompted interest in the nechanism of judicial decision-making. Llewellyn claimed that the formalistic method allowed judges to justify a decision for either side in any case

belief that one evaluates fact or reality (the ls) by comparison to a theoretical or transcendent ideal (the Ought). See note 56 infra.

5. See Ackerman, Law and the Modern Mind: by Jerome Frank, 103 DAEDALus 119 (1974).

6. For a formalistic attempt to solve the necessity for judicial deferral in a democratic society, see Dworkin, Hard Cases, 88 HARV. L. REv. 1057 (1975). Dworkin provides a useful methodology for explaining a decision in any particular case, given a legitimate legal system. However, his static analytical tool does not provide the basis for a normative theory for choice between competing systems, and thus does not answer the ultimate challenge of the legal process school-the problem posed by the "fact-value" dilemma. 
worth litigating (particularly through the appellate stage) by taking advantage of the "leeways of precedent."

Although Llewellyn recognized that rules and precedents created limits on judicial choice to the extent that decisions needed to be justified, ${ }^{8}$ he nonetheless concluded that "[judges] make the law by voicing what had not been voiced before, and how they voice it-both in spotting the issue, and in phrasing it, as well as in the sharp or loose phrasing of the solving rule, and in the limitation or extension and the direction of issue and of phrasing itthat "how' is creation by the judges." 9 After all, if rules and principles really decided all cases, why did so many hard, close cases reach appellate litigation? Surely hard-nosed lawyers could read the rule even if their clients could not, and surely those lawyers hopeful of an aberration, miracle or change in the law would concede the authority of trial courts who dashed those slim hopes.

To deal more realistically with judicial decision-making, Llewellyn wanted to concentrate on the process by which a unique and richly textured factual dispute reached resolution-on how the particular facts affected the decision-maker, and on how the particular decision-maker affected the facts. Making clear the intricacies of the process would improve the chances for streamlining and reforming the institution of law to better meet whatever purposes law could be thought to further. ${ }^{10}$ The improvement would not be merely technical, as Llewellyn's biographer, William Twining, has described: "The central precept of Llewellyn's realism, 'see it fresh,' was a reminder to stay close to the actual and the particular and thus to avoid the chief pitfall of formalism, that of oversimplification through remoteness from day to day reality . . . "11 The perceived importance of staying close to the facts rested upon a skepticism of rules which was itself based on two grounds:

7. [I]n any case doubtful enough to make litigation respectable the available authoritative premises-i.e., premises legitimate and impeccable under the traditional legal techniques-are at least two, and . . . the two are mutually contradictory as applied to the case in hand. Which opens the question of what made the court select the one available premise rather than the other.

Some Realism About Realism 1239. See Twining 205; A Realistic Jurisprudence 443.

8. "[W] cases and down again to the same dispute, there are not so many that can be built defensibly." THE BRAMBLE BUSH 73. Llewellyn listed fourteen factors which tend toward decisional stability. See The Common Law Tradition 19.

9. Llewellyn, Law and the Social Sciences-Especially Sociology, 62 HARV. L. REv. 1286, 1296 (1949). See The Bramble Bush 73.

10. See K. Llewellyn, The Relation of Current Economic and Social Problems to the Restatement of the Law at 25 (1923) (address before the Academy of Political Science). See also Llewellyn, The Crafts of Law Re-Valued, 15 RockY MTN. L. REv. 1 (1942).

11. TWINING 369. 
The first lies in a conviction that "reality" is a thing too complex, tumultuous, and vital to be kept in a straightjacket of rules . . . . The other ground . . . lies not so much in a belief in the impossibility of the task imposed on rules as in a belief in the essential impotence of rules themselves. Rules are made up of concepts, and concepts are but shadowy figments of our own minds, wholly unworthy of the simple faith the conceptualist places in them. ${ }^{12}$

Llewellyn did not deny the importance of rules as a component of law. But he was skeptical of the law in books; he believed the real rule of the case to be that drawn from reformulations of the book rules through their application to each unique factual dispute encountered by judges or legislators. ${ }^{13}$

Llewellyn's belief in the subjective nature of abstractions reinforced his belief that non-legal factors loomed more important than rules in the books in predicting the outcome of those cases which could be decided for either party: "The jurist is protesting against the dogma of his fathers that law is unchanging, eternal, discoverable always by deduction. Only recently has he come to see it as a thing in flux, and made discovery of non-legal factors which condition its growth and action." 14 Flux resulted from either changes in technology or changes in value orientations.

But whether the source of change is technology, value or both, Llewellyn's concept of the need and purpose of law hinged on the ability of the legal system to cope with such movements:

[The job of law and government] for any group, for any community, for any political entity, for any society, [is that of] becoming and remaining and operating as enough of a unity, with enough team work, to be and remain recognizable as a group or as a political entity or as a society .... [I]t is the job of producing and maintaining the groupness of a group. ${ }^{15}$

"Law makes order express." 16 Rules are stated in the course of deciding law in current cases.

Without order there is no group life, there is no group. If the members of a group do not ... manage to live together, if their respective

12. Fuller 443 .

13. The ambiguous use of the term "rule" to mean either an abstract principle or an operative formulation of a decision caused many of Llewellyn's critics to misinterpret his meaning.

14. Llewellyn, The Effect of Legal Institutions Upon Economics, 15 AM. ECON. Rev. 665 (1925).

15. Law and the Social Sciences, supra note 9, at 1291-92 (emphasis in original); see Llewellyn, Law and the Modern Mind: A Symposium, 31 CoLUM. L. Rev. 82-90 (1931); Llewellyn, The Normative, the Legal, and the Law-Jobs: The Problem of Juristic Method, 49 YALE L.J. 1355, 1360 (1940).

16. The Bramble Bush 117 (emphasis in original). 
conduct is not to some degree oriented with reference to each other, if there is not some cooperation, some self-restraint, some specialization and some predictability for each one as to how the other will act when they cross his path, you do not have a group. And the group becomes more a group and less an accidental accumulation of several individuals in one spot, precisely as this order becomes increasingly definite, increasingly certain, increasingly extensive . . . . Settlement of disputes, in any fashion, means reestablishment of the old order, or as the case may be, a new establishment of a somewhat different order in the group. ${ }^{17}$

Law then is the essence of a group, its cement. And "the subject matter of its thinking it borrows from the whole stock of practices, standards, ethics, that make up the social, economic and religious phases of society. What is dominant in society, then, is dominant in law." 18 At times, law maintains order at the expense of progress; at other times the brake of order proves salutary. ${ }^{19}$ In any event, Llewellyn wanted the instrumentality of law to be openly recognized. Judges should adopt a period "style" 20 closer to the great opinions of early American common law judges whose "Grand Style" tested decisions by life's pragmatism, ${ }^{21}$ each rule with its own "singing reason." 22

If one were to summarize in a sentence Llewellyn's primary concern in law, it would resemble Llewellyn's own injunction: "[O]ne concerned with law as a social science, a science of observation, must center his thought on behavior, on the interactions between the behavior of law-officials and behavior of laymen.",23

\section{CRITIQUE: From the High TOWERS}

The realists may be open to valid criticism in many facets of their doctrine. In specific instances Llewellyn, carried away by his flamboyancy, overstated his case and even seemed to contradict it. But when one focuses on the fact-value distinction, the critics have simply misstated Llewellyn's argument. Even sophisticated critics like Fuller and Pound have fallen prey to the seduction of fact-value terminology.

17. Id. at 108 (emphasis in original).

18. Id. at 117 .

19. The Effect of Legal Institutions Upon Economics, supra note 14, at 668-69.

20. Cf. Llewellyn, On the Good, the True, the Beautiful, in Law, 9 U. CHI. L. REv. 224 (1942); Law and the Social Sciences, supra note 9.

21. See W. Rumble. American Legal Realism 201 (1968).

22. Twining 495. See The Common Law Tradition 183.

23. Llewellyn, Legal Tradition and Social Science Method-A Realist's Critique, in EsSays ON RESEARCH IN THE SOCIAL SCIENCES 89, 90 (Brookings Institution, Washington, D.C. 1931) (emphasis in original). 
Basically, the critics saw in Llewellyn's concentration on isolating the "facts" of judicial decision an abdication of responsibility for determining in a rigorous way the correct structure of legal institutions and a standard for judging their decisions. The sin occurred in restricting inquiry to "fact," in insisting that questions of technique be paramount, in slighting normative questions of legal process and substance because those questions were not capable of empirical investigation. ${ }^{24}$ Llewellyn's law seemed amoral, almost lawless.

Overstatement gripped the outcry of men like Herman Kantorowicz, Carl Friedrich and Walter Kennedy who rushed to the defense of the higher order of law, whatever its implementational shortcomings. From Friedrich, "[Llewellyn] has found what works; that is all he cares about, or rather seems to . . . . "25 Kennedy was no less strident in finding, "The particular issue . . . is the contest between the force and validity of principles, precedents, reason, free will, and impartial justice on the one hand, and the impact of emotion, irrationalism, bias, environment, and juristic skepticism in the legal order." 26 Kantorowicz charged Llewellyn with not recognizing analytically distinct concepts of explanation and justification, law and ethics, reality and meaning, concluding:

The realists' conception of the Law, their substantive thesis, is therefore: the Law is not a body of rules, not an Ought, but a factual reality. It is the behavior of certain people, especially of the officials of the Law, more especially of the judges who make the Law through their decisions, which, therefore, constitutes the Law. ${ }^{27}$

24. That this charge is groundless can be seen in Llewellyn's work with the quite prescriptive Uniform Commercial Code. Cf. Llewellyn, On Warranty of Quality, and Society, 36 Colum. L. Rev. 699 (1936); Llewellyn, On Warranty of Quality, and Society: II, 37 Colum. L. REv. 341 (1937). But see Danzig, A Comment on the Jurisprudence of the Uniform Commercial Code, 27 StAN. L. REv. 621 (1975). To presage the general argument of this section, Danzig recognized Llewellyn's concern that law reflect the mores of the group with which it is concerned. However, he failed to escape the traditional separation of fact-observation and value orientation. See id. at 629-30. Thus, Danzig felt that Llewellyn's judges were charged with an impossible task, given a "triad of dubious assumptions that self-evident ideal resolutions of situational problems exist, that they can be discovered by careful scrutiny of actual situations, and that once articulated they will be widely accepted." Id. at 635 . But these are not Llewellyn's assumptions. A more accurate triad would posit that ideal resolutions are contextually defined by the shared values of the groups represented in the litigation; that judges sensitive to the unique, dynamic situation which spawned the case can approximate application of the value-laden solutions derived from experience; and that the judges' success in statically approximating this dynamic ideal resolution will determine whether their pronouncements will be widely accepted.

25. Friedrich, Remarks on Llewellyn's View of Law, Official Behavior, and Political Science, 50 PoL. SCI. Q. 418, 428 (1935).

26. Kennedy, My Philosophy of Law, in My Philosophy of Law: CRedos of Sixteen AMERICAN SCHOLARS 147, 157 (Julius Rosenthal Foundation 1941).

27. Kantorowicz, Some Rationalism About Realism, 43 Y ALE L.J. 1240, 1243 (1934). 
Such criticism, based on faulty assumptions about Llewellyn's work, falls upon cursory examination. First, the critics have assumed Llewellyn wrong in his evidence that abstract rules incompletely state the true rules of legal dispute resolution, that the rules fail to account for the actual application of abstractions to concrete situations. Second, they have assumed that concern over what happens in particular legal actions was his exclusive interest, that investigation of behavior was not related to a particular view of law's purpose. Third, the critics have assumed that conceptual thought provides the exclusive test of truth in criticism, that the Ought must be entirely distinct from the Is. The third assumption must be analyzed separately; Llewellyn himself vigorously protested the others.

The task Llewellyn set for himself was not to ignore the Ought at all, nor even to divorce the Ought from the Is in actual judicial decisions. Rather, he sought to distinguish discrete data and questions in the investigation of past occurrences and cases. According to the critics, Llewellyn's mistake of statement lay in his belief that such static analysis of fact in a courtroom or appellate brief could be meaningfully carried on in a value-free or "objective" state.

That the original furor misinterprets Llewellyn entirely should be clear from the text most frequently attacked by critics, in which Llewellyn set out a premise common to realist thinkers:

The temporary divorce of Is and Ought [is] for purposes of study.

By this I mean that whereas value judgments must always be appealed to in order to set objectives for inquiry, yet during the inquiry itself into what Is, the observation, the description, and the establishment of relations between the things described are to remain as largely as possible uncontaminated by the desires of the observer or by what he wished might be or thinks ought (ethically) to be. ${ }^{28}$

Harry Jones explains the difficulty clearly: "The analytic separation that Llewellyn chiefly wishes to preserve was less that between the doctrinal Is of analytical jurisprudence and the ethical Ought than it was that between the Is of law in action (what courts are doing in fact) and the normative Ought of the law in the books." 29 When Llewellyn insisted the realists held no normative program, he meant not that each realist was unconcerned with morality in law, but that the way of improved law depended on fully knowing the operation of law. ${ }^{30}$

Without regard, momentarily, to whether such a program could be pursued, the substance of a slightly more sophisticated, normative critique

28. Some Realism About Realism 1236 (emphasis provided).

29. Jones, Law and Morality in the Perspective of Legal Realism, 61 CoLUM. L. REv. 799, 808 n.32 (1961); see A Realistic Jurisprudence 443, 448.

30. Some Realism About Realism 1254-56. 
should be examined. Critics such as Fuller wondered what standard did govern the operation of law when the prescriptive in law was temporarily set aside. What was the realist looking for in all those "facts"? Fuller seemed to feel that the is-ought distinction led Llewellyn to incoherence: "The modern realist is still not clear in his own mind whether he objects to 'conceptualism' because it fails to achieve an accurate formulation of its principles or because it pretends to proceed according to principle at all."31 "[T]he cleft between Is and Ought causes acute distress to the realist."32 "[H]e is not sure whether his prescription is to force life into conformity with a new, more carefully drawn set of rules or to permit rules to give way to life."

Again it seems Llewellyn's own answer should have been clearrealism's basic tenet held that abstract propositions could be made to fit any set of facts sufficiently complex to be properly in litigation. Either numerous prior precedents allowed sufficient leeway to justify a technical decision for either party, or infrequent concern with the underlying issue allowed sufficient abstraction in precedent for the applicable standard to be interpreted in diverse ways. What one needed was a tool of insight to determine which rule would govern in a close case. Fuller's concern stemmed from uncertainty that a non-conceptual standard could be isolated. Llewellyn, on the other hand, believed that better knowledge of the process would lead to better rules, and a concentration on explaining and justifying those rules. Rules were to possess a "singing reason" which explicitly included the static policies or ends which represented the dynamic needs of the group. The false dichotomy attributed to the realists by Fuller-meeting the particularities of specific cases by either prescribing greater specifications in each rule, or rejecting rules in favor of ad hoc policymaking-ignores a possible third alternative for Llewellyn. Rules may remain conceptual (static) conventions but draw their meaning and their application from pragniatic particulars - the habits and shared conventions of life-and not from universals abstracted from dissimilar past occurrences (except to the extent that understanding the past leads to understanding of the current controversy). Part of any pragmatic evaluation of a present controversy involves the dynamic interaction of currently held visions of what a set of particulars is expected to mean with the simultaneous experience of those new particulars. If the expectations are not seriously jarred by the new situation, the actions of one party or the other, or neither, may be said to approximate an approved manner of behavior.

31. Fuller 462.

32. Id. at 461.

33. Id. 
In setting forth his personal standard of the Ought which should guide choice of law, Llewellyn described his philosophy as that of a lawyer's natural law. It was not until the end of his career, however, that he firmly articulated this credo:

Every fact-pattern of common life so far as the legal order can take it in, carries within itself its appropriate natural rules, its right law. This is a natural law which is real, not imaginary; it is not a creature of mere reason, but rests on the solid foundation of what reason can recognize in the nature of man and of the life conditions of the time and place; it is thus not eternal nor changeless nor everywhere the same, but is indwelling in the very circumstances of life. The highest task of law-giving consists in uncovering and implementing this immanent natural law..$^{34}$

Placing the above language in the context of all Llewellyn's writings makes it clear that he was normatively concerned with law's operation. He simply felt that static analysis would help clarify the immanent and dynamic norms of law in action. ${ }^{35}$

To pursue the previous thought, can Llewellyn's methodology of temporary is-ought divorce be meaningfully accomplished? One of Llewellyn's earliest critics set perhaps the most sophisticated tone:

If recent philosophy teaches aright, there is no absolute reality. What test of reality may a modern relativist assert in jurisprudence other than significance? But there is no absolute significance. Significance is significance for, or in relation to something. ${ }^{36}$

Here Pound wanted to know what standard the realist would use in choosing which static factors to examine and then use in evaluating those choices. When Llewellyn answered, "[A]ny sound socio-jurisprudence turns on analysis of what the institution of law is for, and how it goes round, with one's fighting convictions on the former never allowed to interfere with accurate observation of the latter, $" 37$ he stated the conclusion only. Pound still questioned the feasibility of accurate observation:

Thus preconceptions will creep in and will determine the choice of pure fact of fact as they determined the pure fact of law of the analytical jurist. The new realists have their own preconceptions of what is

34. The Common Law Tradition 122. See On the Good, the True, the Beautiful, in Law, supra note 20, at 242; Llewellyn, One "Realist's" View of Natural Law for Judges, 15 NotRE DaME LAw. 3 (1939); Rohan, The Common Law Tradition-Situation Sense, Subjectivism, or “Just-Result Jurisprudence?”' 32 Fordham L. Rev. 51 (1963). But see Twining 216-18.

35. " $[A]$ Realist's interest in Fact, and in the meaning of people to law and of law to people, in no measure impairs interest on his part for better law," Llewellyn, Through Title to Contract and $a$ Bit Beyond, 15 N.Y.U.L. Rev. 159, 162 (1938).

36. Pound, The Call for a Realist Jurisprudence, 44 HARv. L. REv. 697, 699 (1931). Less sophisticated versions of Pound's objection appear in TwiNING 225; Ackerman, supra note 5, at 122.

37. On the Good, the True, the Beautiful, in Law, supra note 20, at $224 \mathrm{n}^{*}$ (emphasis in original). 
significant, and hence of what juristically must be. Most of them merely substitute a psychological must for an ethical or political or historical must. ${ }^{38}$

It would be a mistake to think that Llewellyn did not attempt to answer the charge, although again, the definitive answer was more implicit than explicit. In The Common Law Tradition, he responded, "What realism was and is, is a method, nothing more, and the only tenet involved is that the method is a good one." 39 The final clause is critical. Llewellyn meant that in isolating which factors controlled (defined) past decisions, static analysis of those decisions must be used to the point that it contributes to understanding the present case.

That Llewellyn at least intuited the artificially static nature of objects of analysis as opposed to the dynamic law process will be demonstrated in later sections. But evidence can be found in Llewellyn's recognition that the only objectivity of static precedents stems (like language) from the possibility of their agreed applicability to slices of reality. Such a concession would be anomalous if "factual" analysis were thought to be purely objective. Although his most comprehensive statement did not appear until the 1960 Common Law Tradition, ${ }^{40}$ Llewellyn conceded the value-laden nature of listing facts in a particular case, 41 interpreting and evaluating "factors" which affect decision, ${ }^{42}$ classifying fact types, ${ }^{43}$ and deriving actual "rules" of decision (as opposed to for decision). ${ }^{44}$ But he went on to assert that this realization should not be a reason for not investigating. It is simply a reason to be careful or prudential, and to remember that one should only categorize real experiences in static factual conventions when "necessary to the accomplishing of a purpose." 45

Fuller picked up the remaining psychological argument, positing that Llewellyn's obsession with the conventions of "factual" data led him to a form of nominalism. ${ }^{46}$ But Fuller, wedded to the traditional separation of

38. Pound, supra note 36 , at 700.

39. THE COMMON LAW TRADIrion 510. Rumble's suggestion that Llewellyn called his theory a "method" in order to put off critics like Pound seems out of place in light of this later passage. See W. Rumble, supra note 21 , at 35 .

40. It is of course vital that the factual impact of these clusters of factors [which bear with regularity on the way in which appellate cases get decided] be discussed as a factual matter, undisturbed by any question of whether you or I ought to be approving or indorsing or applauding whatever it may be that is going on. I shall therefore attempt to limit text .. . to simple observation and description. But these are matters which involve value-judgements . . . both about objectives and, when one approves one or another objective, value judgments about measures . . . .

The Common LAW TRADITION 16.

41. See Twining 233-34 (quoting The Bramble Bush 48).

42. See Law and the Social Sciences, supra note 9, at 1295-97.

43. TWINING 233-34.

44. For all four stages, see The BRAMBLE BuSH 72.

45. A Realistic Jurisprudence 453.

46. This error may be stated as the belief that the individual in his own private thinking 
fact manipulation and evaluation, assumed that Llewellyn also depended upon a reason which dealt only with objects. Fuller failed to see that inherent in Llewellyn's thinking is the concept that observation and criticism are a unitary function; failed to see that the dynamic thinking about concepts differs only in degree from thinking about "things"; failed to see that while static conventions provided the only means of communication for Llewellyn, they still serve to explicate our dynamic thinking process, albeit in a misleading and approximate manner. Focus on the communicable does not exhaust Llewellyn's view of thought. In short, what Fuller did not demonstrate is that Llewellyn missed an important function in his view of thought, a function supplied by reference to an abstract, conceptualist division of fact and value. In fact, if Fuller differs from Llewellyn at all, he seems only to have been reifying a conventional or analytic distinction when he concluded with what appears to have been a description of Llewellyn's very process in unfamiliar terms:

The fact is that from the standpoint of individual psychology the concept is not a container or "thing" at all, but an activity of the conceiving mind. The "thingifying" comes about when we convert this mental activity into logical terms. It may be that this process of converting a dynamic activity into a static "thing" necessarily involves some distortion. ${ }^{47}$

When this static-dynamic distinction is understood as both Llewellyn and Fuller understood it, the passage Fuller chose to illustrate Llewellyn's sin is at best paradoxical. It seems one of the strongest examples of Llewellyn's allegiance to dynamic process:

Let us assume a case not involving any doubt . . . . Even here there is an enlargement, a reformulation, an importation of something new into the rule. For the rule consists of a series, a complex of word-symbols. In itself a symbol is nothing. A symbol is, however, a means of pointing to things or thought-constructs. Insofar as things were demonstrably aimed at in the original use of a symbol, the symbol has from the beginning content. Every symbol, however, has to an uncertain degree something which we may call latent content, a capacity for expansion, as it were, which though partly equivocal and unforeseeable, is also in part unequivocal and foreseeable. ${ }^{48}$

The interplay of dynamic process and static convention runs throughout the quotation.

does not employ universals and abstractions and that these things are only convenient devices for the communication of ideas. It is the notion that in the internal economy of the mind only "things" are dealt with, and that abstractions and concepts are simply packages of these "things" bundled together,-for export purposes, as it were.

Fuller 444 .

47. Id. at 447.

48. Id at 445 (quoting in translation K. Llewellyn, PRAJUdIZIENRECHT UND ReCHTSPRECHUNG IN AMERIKA $72-74$ (1933)). 
Pound-like criticisms have been stated with less development by a number of other authors. Friedrich claims that "Llewellyn's scheme of references for the ordering of his regularities is determined for him by the officials who make the law." 49 In a sense, of course, this is correct; the official's behavior as an administrative or appellate judge is the dynamic stuff of experience which interested Llewellyn. But the regularities (static conventions) which he "took" from these officials were his conventions, and thus, as he recognized, subjectively value-laden. Friedrich's is a noncritique. ${ }^{50}$ Additionally, the criticism ignores Llewellyn's emphasis on the experience of the users of the law as both the source of law and the criterion by which it must be evaluated. 51

When Hart observed that some cases were indeed plain and clear according to the paper rules, ${ }^{52}$ it is difficult to determine whether the statement was meant gratuitously or to indicate that Llewellyn's fact-focus

49. Friedrich, supra note 25 , at 420 .

50. But see Verdun-Jones, The Jurisprudence of Karl Llewellyn, I DALHousie L.J. 441 (1974). Verdun-Jones takes up Friedrich's mistaken observation that Llewellyn is concerned exclusively with observing the "facts" of official behavior without offering a theoretical model which orders those observations or which suggests hypotheses to test by observation. Id. at 451-52. "However, as we have seen, Llewellyn does not take a systematic approach to the decision-making process . . . Llewellyn's performance of the projective task once again paves the way for future research but it does not deserve the recognition of being either scientific or comprehensive." Id. at 479. "[T] he theory does not provide for a study of such vital elements as the structure of social and legal institutions, the power process, and the creation of policy." Id. at 451. Because Verdun-Jones attributes a traditional notion of fact and value separation to Llewellyn, he fails to recognize the coupling of Llewellyn's institutional concepts (see generally The Normative, The Legal and the Law-Jobs, supra note 15; see notes 53 and 100 infra and accompanying text) with a pragmatic normative system through the models of the Grand Style and its method of situation sense (see text accompanying note 34 supra, and note 53 infra). In short, "the central precept of Llewellyn's realism, 'see it fresh,' was a reminder of the need to stay close to the actual and the particular and thus to avoid the chief pitfall of formalism, that of oversimplification through remoteness from day-to-day reality; whereas the other precept of realism, 'see it whole,' emphasized the need for a coherent frame of reference. Cautious striving towards the establishment of significant patterns, as embodied in the concept of 'situation sense,' was Llewellyn's main formula for resolving the basic dilemma." TwINING 369. Thus, Verdun-Jones' conclusion, "[T]hese so-called keys to wise decision do not furnish us with even the barest skeleton of a systematic procedure for evaluating policy alternatives" (Verdun-Jones, supra, at 481) assumes "situation sense" does not contain an evaluative component; that Llewellyn, as well as he, meant by "the temporary divorce of Is and Ought," a separation of fact and value. This Article argues that the assumption is incorrect in light of the full context of Llewellyn's work.

51. Law's "singing reason" looks to experience to inform the choice of value-laden outcomes and judges this legal performance with the behavior which results. Llewellyn put this philosophy into practice as Co-reporter for the U.C.C. Each section was written for the groups most likely to utilize them. For example, Article Two on sales was written far less technically than others (such as the boilerplate, investment securities Article intended for lawyerspecialists) with the intent that lay businessmen and general practitioners could read and live comfortably with it. I am indebted for this insight to the other Co-reporter, Dean Soia Mentschikoff.

52. See H.L.A. HART, ThE CONCEPT OF LAW 123, 135-36 (1961). 
will not be the exclusive method of decision. Llewellyn would respond that plain cases simply indicate completely shared values-cases that need not be brought to an institutional resolution. ${ }^{53}$

Finally, Edward Bloustein has dressed up Hart's objection by asserting that "The fundamental error of the Realists is that they confuse a logical reason in Law with a logically necessary reason." 54 To the extent that Bloustein would appeal to Hart's "plain" cases, Llewellyn would note the begging of his question. Whether the judge's paper rule is even a logical reason can be questioned in all tough cases. But more basically, no realist ever claimed precedent and rule to be irrelevant to legal decisions. Past shared conventions are always important to new shared conventions (assuming a rational, well-meaning judicial interpreter of conventions). Such an observation, however, does not control the choice of what convention to apply-a point that slides past Bloustein and Hart.

Why should all the critics of realism who concentrated on Llewellyn's alleged misuse of the fact and value distinction have failed to see the many preemptions of their arguments in his writings; why should they not have attempted to read his material sympathetically to maintain its coherency? The misstatements seem so glaring, simple negligence does not satisfy. The deeper explanation must be that their own particular tie to the traditional, liberal statement of the fact-value distinction made Llewellyn's denial of the independent efficacy of value or Ought dangerous. Llewellyn of course contributed; he used the only terminology available to him. But he used it at least subconsciously to posit an explanation of legal behavior different from what his critics had yet experienced. Even for those thinkers uneasy over orthodox doctrine, Llewellyn seemed extreme and unwise. From Fuller, "What I fear is that he may suffer from a species of color blindness which causes him to see one part of the picture with especial vividness while the rest fades into an indistimct background." 55 The color blind Llewellyn merely saw experience through different epistemological glasses. Llewellyn's rules and abstracts were different. They included both fact and value.

\section{Methodology: Reaching For the GaRMENT'S HeM}

It will be the argument of this section that a set of premises concerning the nature of man and the attainment of both knowledge and political order

53. The people who do a certain thing get to doing it in a certain way. They get to expecting it to be done in a certain way. When this process has gone far enough and long enough to take on the shape of a definite, standard practice, we have the raw stuff for the law to take hold of and work on, and the legal institution will be built according to the mold of the life it finds already being lived.

The Relation of Current Economic and Social Problems to the Restatement of the Law, supra note 10 , at 27 .

54. Bloustein, Logic and Legal Realism, 50 CORNELL L.Q. 24, 29 (1964)(emphasis in original).

55. Fuller 450. 
superior to those of dominant Western liberal social theory ${ }^{56}$ does not require the fact-value distinction. ${ }^{57}$ If such an argument can be plausibly maintained, critiques of "realistic" jurisprudence which rest on the charge that realism forces a collapse of that which "ought to be" into that which "is" can be safely disregarded. The real answer proposed by this Article is that Karl Llewellyn, read consistently, seems to have been pushing at the edges of a reconciliation of fact and value as applied to legal experience. If so, then the historical vanguard of a non-liberal tradition in law may have been forming among the legal realists in the 1920's. If it can be shown that the germ of a new social-philosophical paradigm inhered in the legal theory of the realists, then the broader theory posited here gains the sanction of limited historical acceptance. And if so, then the transformation of the realists "non-doctrines" into the legal process doctrine which now dominates modern legal theory marks a misdirected return to liberal foundations. ${ }^{58}$

Roberto Unger has persuasively argued the need for a new post-liberal set of foundations beginming with a view of the cognitive self determined and defined no differently than that of the hiberal system. Under this view:

[C]haracteristics of the self are both facts and values, and the doctrine that describes them is simultaneously descriptive and evaluative.

56. Briefly, the liberal paradigm develops from these premises: First, liberal man is seen as fundamentally pre-social-his nature can be defined apart from the social structures he has built, or the idiosyncracies and existence of any given individual. Second, man possesses a subjective faculty which desires a personal set of wants and needs. Third, following Hobbes, and given this universal man's subjective relation to the world, man in his hypothetical presocial situation finds that his needs and wants exceed his individual ability to satisfy them, given the rivalry of like-minded pre-social men. Fourth, while each individual seeks satisfaction of individual wants, man possesses a universal faculty of reason, distinct from desire, allowing intercourse between men and thus the formation of societies for the promotion of individual wants and protection. Reason operates distinctly from desire: the subjective faculty identifies the objects of man's pursuit, the objective faculty permits their systematic attainment and the subjective again evaluates the success of their achievement, thereby providing the motive and precedent for new subjective choices. The faculty of reason is thought to be universal and objective because all men are observed to act with regularity in pursuit of their wants, thereby recognizing the possibility of social organization. The ethic of individualism reconciles itself to some loss of autonomy solely to enjoy a remaining degree of control over the means to satisfy subjective wants. The resulting level of satisfaction is perceived to be greater than that which would exist for the individual part from organization. All legitimate societies are then but aggregations of individuals. Fifth, and more generally, such interaction is only possible if each subjective being relates to the external world on the basis of personally observed regularities which then may be conventionally defined, and aggregated into larger and larger pictures of experience. The external world, like society, becomes estranged and separate from the subject-man. Two realms exist, fact and value, necessitated by the separation of object and subject. Reduced to its most basic formulation, the common philosophical, psychological and political-economic assumption of the liberal theory's paradigm is that the whole is always exactly equal to the sum of its parts. See generally R. UNGER, KNOWLEDGE AND POLITICS 36-38, $64-67,105,125$ (1975).

57. $C f$. sources cited in id. at $301 \mathrm{n} .18(\mathrm{c})$.

58. Cf. Ackerman, supra note 5, at 123. 
Evaluation and description meet at the point at which one defines human nature. There is perhaps nothing to say to a man who would like to be a centaur. ${ }^{59}$

One may begin the construction of post-liberal premises with the justified (because plausible) assumption that the basic defining characteristic of human nature is the attainment, preservation and manipulation of knowledge. In turn, the concept of knowledge implies cognition, something more than a stimulus-response relationship between the self and the external world. It is an experience of consciousness in which it is meaningful for the self to believe that both it and the external world are concrete and existentas if the world actually is as it seems. The self believes itself to be autonomous; in its relation to the world, it is not limited to a finite, singular set of responses, "natural" or learned, but believes itself capable of choice in perception and action. ${ }^{60}$ Cognitively, the autonomy is also completely subjective-whatever the actual physical relationship of the self and the world, all characterizations and hence all communicable knowledge of those relations are purely conventional. ${ }^{61}$ In fact, as technological change makes it possible for the experiences of different selves to diverge radically and thus for symbolic understanding of the common world to differ widely in both kind and degree, any "objectively" held beliefs at all (even in the natural sciences) $)^{62}$ become less plausible. Hence, to the degree that any knowledge can still be thought of as objective, the objectivity must be subject-centered

59. R. UNGER, supra note 56, at 196. A particular confusion must be avoided. A model of the self which simultaneously describes and values what it is to be human (the anchor concept) has been implicitly accepted and shared throughout history, and has thereby been legitimated. Given this view of the self, a separate question arises as to the nature of the relationship between the self and the external world. An epistemology which also involves a descriptiveevaluative fusion may be justified on the basis that it is more consistent and coherent for the historical anchor concept than is the liberal epistemology, which would sever the descriptive and evaluative functions-and against which the fusion within the self is set.

60. R. UNGER, supra note 56, at 204.

61. Conventional knowledge can be defined as the symbolic meaning assigned by the self to an experience of regularity which is believed to be discretely explained or identified by that symbol.

The reasons for the ascendancy of such a view of the self lie beyond the argument here. Suffice it to note that the alternative view, based on an immanent-essential ideal, or a transcendental-determined ideal, will not do. The immanent-essential ideal posits that each object can only be identified and criticized in accordance with its unique, unchanging essence. The divergence of the natural world and the changes wrought on that world by man necessitated a critical advance on the immanent-essential ideal. See R. UNGER, supra note 56, at 159-60. Its descendant-the transcendental-determined ideal-holds that an object can be truly known and evaluated only when compared to an objective, pre-determined ideal whose source lies beyond man. Both of these constructs, however, become untenable in an age in which man believes that no accomplishment, no alteration of the external world lies beyond the reach of his technological capabilities. When the world becomes completely manipulable, all knowledge must be mancentered (or, at the very least, man-interpreted).

62. See T. Kuhn, The StRucture of Scientific Revolutions (1970). 
in man-that is, shared. It would seem that man must come to terms with this radical subjectivity, albeit within an inescapable social setting. The key problem of the age may well be the preservation of autonomous consciousness within social organization. ${ }^{63}$

This tension between individualism and social existence is important in that while the individual's stock of knowledge-his conventions-will increase automatically as his experience increases, ${ }^{64}$ the essential element in the advance of existent understanding of that experience is criticism. Immediate questions arise as to the nature of criticism and the test of its legitimacy. The dominant social-political-philosophical tradition, liberal theory, breaks the function of criticism into two components: the ability to make "factual" or descriptive distinctions between entities encountered by the self, and the ability to "value" or ascribe characteristics to the entity. To account for these two functions, liberalism created two corresponding faculties: reason, to distinguish facts and courses of action, and desire, to value and provide the motive for choice.

However, the assertion runs, a more coherent theory of criticism does not depend upon this division of reality ${ }^{65} \mathrm{It}$ is clear that no positive physical reason exists to demand the dual faculties. In keeping with the belief in the subjective conventionality of knowledge, reason and desire would seem to be simply conventional constructs for describing observed regularities in space and time. They appear to be two distinct functions-distinct, because the function of criticism would seem to require that the way things are may not be the same as the way things ought to be-an observation which forms the basis for the traditional fact-value distinction.

But because the only basis for knowledge of the external world is individual experience of it, the perceived conventions come to be taken as existential whether or not any further physical evidence substantiates the convention. ${ }^{66}$ Yet, at least in dealing with objects in the external world, our conventions can be checked pragmatically. In perceiving the self, such corroborating direct experiences can only be internal; it is thus difficult to find a similar workability criterion to distinguish reality from its perception. The conventional nature of descriptions of the self can therefore be easily

63. One can speculate about an abstract model of man divorced from social living but the relation of the speculation to the experience of living in the twentieth century will be problematical at best. Life has come to be experienced as social.

64. "Our fields of experience have no more definite boundaries than have our fields of view. Both are fringed forever by a more that continuously develops, and that continuously supersedes them as life proceeds." W. JAMES, EsSAYS IN RADICAL EMPIRICISM 39 (R. Bernstein ed. 1971). See R. UNGER, supra note 56, at 204.

65. In support of the epistemological arguments made in this section, see generally $\mathrm{J}$. DeWEy \& A. BeNTLEY, KNOWING AND THE KNOWN 119-21 (1949).

66. See id. at 137. 
forgotten. If the fact-value distinction and its psychological basis in the reason-desire faculties are reifications of purely analytic conventions, two errors may arise in continuing their symbolic use: (a) the ambiguous use of fact, and (b) the subordination of evaluation to the requirements of static communication.

\section{A. The Ambiguity of Fact and the Static-Dynamic Distinction}

The term "fact" is the name given any conventional representation of an entity or thing, any observed regularity or singular concept which is capable of symbolic communication. But the term also stands for the real object which underlies the communicable symbolic representation. It may or may not be taken as a premise that this conventional symbol is meaningful because of its direct relationship to the real entity, but it is a leap of faith to believe that the facts of conventional knowledge are exactly congruent to the facts of the real world or that they reflect the mechanics of the actual thought process of the real self. ${ }^{67}$ That they may be does not alter the assertive character of the relationship.

It seems clear that conventions can never be exactly analogous to reality. The conventionality of naming experience means that the result must be a static snapshot of the experience. On the other hand, it is a fundamental experience of the self that it is in continual motion, not a stop-start progression of statics. "Our lived experience does not consist of regularities of static units; we directly experience and feel transitions."68 "Continuity can't mean mere absence of gap; for if you say two things are in immediate contact, at the contact how can they be two? If on the other hand, you put a relation of transition between them, that itself is a third thing . . . and so on." 69

Thus, man experiences the static-dynamic distinction. While we can communicate about on-going experience and can consciously understand an on-going thought process, the conventional communication or preservation of those experiences will cause them to be frozen artificially. Conventions do not remain constant through time, however. Each discrete moment of experience provides the context for the next; the conventions of the past affect the perception of the present, and the present perception adds more to the fund of experience which refines past conventions. ${ }^{70}$ This process may

67. See W. JAMES, supra note 64 , at 29 . Admittedly, this observation is not a new one. In policy science it has long been axiomatic that truth statements reduce to cstimates of probability.

68. Id. at xxii.

69. Id. at 29.

70. The cognitive process of the self continuously moves from thought to thought without break or definition of transition (a seemingly horizontal movement) and simultaneously and continually informs the perception of all past retained experiences (a corresponding vertical 
radically transform or merely reinforce our static description of bits of life we isolate for closer focus. ${ }^{71}$

\section{B. Convention-building and the Limits of Language}

Of course, the manipulation of past experience is itself a dynamic process. ${ }^{72}$ At this point, the problem of criticism should be obvious. By the time (if one believes the traditional account of evaluation) a concept can be written down or extracted from the thought process for analysis, its discrete time has come and gone, and in a very real sense can never be the sanie again, given intervening experience. Communication of critical analysis complicates the task enormously. Only the static symbols conventionally attached to "facts" snatched out of motion are transferrable. The best fact that conventionality can communicate is a snapshot of a shadow of a thing that was, but never is. ${ }^{73}$

Symbols are more than labels, however. The words and concepts which are attached to "things" could not communicate meaning from one person to another or from one time to another if they were drawn from a hat without regard to the regularities of experience. If real facts were static, labels might suffice. But since their perception continually evolves, the context of the experience of the fact as well as its label needs to be transferred in order to achieve mutual understanding of the object of comnunication.

Further, consciousness of the actual implies an ability to distinguish objects. One cannot categorize without a critical perspective. The placing of a fact within the context of past experience ascribes "value" to it in the sense of position, likeness, weight, appeal and the like, giving it "meaning." Such is the difference between understanding and perceiving-the added element of meaning makes the process of thought and choice conscious and deliberate.

What we say about reality thus depends on the perspective into which

we throw it. The that of it is its own; but the what depends on the

disturbance). One might visualize a Cartesian plane which over time becomes a three-dimensional Cartesian space. Cf., e.g., R. PIRSIG, ZEN AND THE ART OF MOTORCYCLE MAINTENANCE 277-78 (1974).

71. See J. DEWEY \& A. BENTLEY, supra note 65 , at 122-24.

72. "We live forwards . . . but we understand backwards." W. JAMES, Pragmatism's Conception of Truth, in The MORal Philosophy OF William James 305 (J. Roth ed. 1969); $c f$. W. James, Pragmatism and Humanism, id. at 315.

73. In more prosaic terms, the court of appeals' reading of a trial court's transcript of recollections of eye-witnesses is of an event perhaps long past in time. The credibility of continued retelling per se is not the point. Rather, it is the focus of the experience set which each communicator of the underlying facts brings to bear on the phenomenon and which causes each to experience his version of the story as a different although approximately similar (it is hoped) event that is in question. Further, while the event may be re-enacted, it can never be reexperienced. 
which, and the which depends on us . . . . Hence even in the field of sensation, our minds exert a certain arbitrary choice. By our inclusions and omissions we trace the field's extent; by our emphasis we walk its foreground and its background; by our order we read it in this direction or in that. We receive in short the block of marble, but we carve the statue ourselves. ${ }^{74}$

Thus, a more realistic explication of these experiences of understanding or knowledge-attainment would recognize that each moment of dynamic experience, if it were to be stopped, would manifest two necessary cognitive operations: description and prescription, naming and valuing, fact and value. These so-called operations can be communicated only as two separate conventions. Yet, if an infinite regression of such conventional definition is to be avoided, each conventionally discrete moment must in reality unite both reason and desire as part of a singular experience. However static and bifurcated our symbolic representations may be, our cognitive experience can only coherently be that of dynamic "fact-values." "75 Understanding is a continuous, organic process, in which "the first premise is not a proposition but a course of action." "76

This process of understanding, though uniquely subjective, does not require a skeptical view of the world. For all practical purposes, the interaction of conscious beings becomes a common experience to which each party attributes a conventional meaning. ${ }^{77}$ The experience remains as a symbol in that convention after the experience itself has ceased or changed. Of course the sharing is of the most approximate kind, dependent particularly on a basic historical convergence of lives before communication is even possible. ${ }^{78}$ But communications come to have conventions of their own, ${ }^{79}$ and thereby approximate meaning is transferred. And as meaning inherently involves an ascription of values, a rudimentary value is also transmitted. ${ }^{80}$ Communication depends on a minimal level of value sharing. It is a simple escalation of complexity for more abstract conventions to be transferred, including complex values or benchmarks for what to choose as well as for value judgments about what has been chosen. After all, modern man does not have to begin fresh in the building of shared values; centuries of familiar history provide a bedrock of beliefs, conventions, languages, theories which may be understood (if not subscribed to) by all men. ${ }^{81}$ That the understand-

74. W. JAMES, supra note 64 , at 25 (emphasis in original).

75. Please note crucially, that as a value or values are also conventionally facts, a similarly disastrous ambiguity can be generated for values as for facts.

76. Attributed to Ludwig Wittgenstein.

77. R. UNGER, supra note 56, at 101.

78. Id. at 113 .

79. Dewey, Logical Method and Law, 10 CORNELL L.Q. 17, 20 (1924).

80. W. JAMES, supra note 64 , at 42 et seq.

81. R. PIRSIG, supra note 70, at 262. 
ing of each man only workably approximates that of the next is an irreducible problem of history but not of analysis. ${ }^{82}$ The dynamic experience of conscious thought inherently includes the dynamic process of valuation. That this process can only be manifested in static duality is a weakness of communications and not of thought. ${ }^{83}$

The liberal alternative of a subjective faculty of desire or the Kantian alternative of splitting abstract and prudential reason to explain valuation not only double counts criticism but is counter-experiential as well. To demand distinct operative faculties of reason and desire makes thought a herky-jerky progression of terminal points which can then be infinitely subdivided with no a priori criterion to determine whether reason or desire controls the process. ${ }^{84}$ To recall James, our continuous experience does not exhibit such gaps.

On the other hand, to split thought into Kantian realms does violence to the common sense continuum of thought, whose stopping points differ in degree only: one thinks about what to identify as our feet, how to tie our shoes, to choose dinner menus, to plan the day, to plan our lives, to find a meaning in the future, to understand the basis of time, to speculate about

82. The impact on the legal system of approximately shared meanings in a pluralistic society is intended to be more completely discussed in a future work.

Men may readily agree to abstract propositions, but the extent of their agreement must remain somewhat problematic. The breakdown of apparent agreement is well documented in law in the dilemma of general rule and specific application.

To generalize: in order to demonstrate the inadequacies of liberal psychology in explaining the transfer of shared values, the experience of part-whole relationships needs to be contrasted with that inhering in liberal theory-i.e., the whole always equals the sum of its parts. Given the confusion created by the static demands of language, static "facts" seem like building blocks, combinable over time to produce more complex, more abstract, static aggregates or wholes. The real entities behind these static conventions, however, never exist in a given state long enough (except as a matter of approximation) to be so perfectly combined. Our "fact-value" particulars or conventions statically represent the way each part of experience is known by a self, its own nature and thought included. The concrete foundation for all our conventions remains the dynamic part of experience. By definition, therefore, the cognition of wholes and parts being continually in "perceptive evolution," the whole is always greater (or conceivably lesser) than the sum of its parts. But also by definition, the conventional universal is never greater than the sum of its conventional particulars. The difference arises in that the static representation never exactly matches dynamic experience.

83. To see the process of understanding or the acquisition of knowledge as value-laden convention-building preserves the function of criticism as a part of knowing what a thing "is." To say that something (a "fact-value," an idea, a theory) is questioned is to say that if the life process were stop-actioned, the value judgment (actually, its conventional manifestation) at that point would have been that something was questionable. To apply an objective ideal or to create a subjective abstract reason different in kind from the process of convention-building creates a system requiring double counting to explain the important process of criticism. That is, when a static convention is deemed questionable, the act of criticism concerns the convention, not the "fact-value" that the convention symbolized; the latter has already been criticized in the convention-building process.

84. Cf. R. UNGER, supra note 56 , at 135 . 
what is beyond time. Common sense would find no dividing line of abstraction; the process of understanding does not demand one.

\section{Objections}

The major objection to the unification of fact and value in understanding is that it would seem to sanctify actuality; the liberal and Kantian dichotomies exist for a purpose-to provide a criterion of choice between theories and to judge the adequacy of the evaluation. The objection is naive on its face. The world may indeed be different than the way we think it ought to be. If it is different in an unchangeable way (given time constraints) experience will also with greater or lesser speed demonstrate that necessity. ${ }^{85}$ But clearly, different people possess different theories to explain what all would recogmize as approximately the same phenomena. The question remains how to choose. If each theory is based upon a different fund of experience, a different personal and cultural history, why should one individual's or one group's theory be more entitled to belief than any other? The short answer is that it should not. Each theory bears the burden of persuasion as to why its universals, its static nature, more closely approximate dynamic reality (or the shared perceptions of that reality). Just as language becomes accepted, so do the paradigms described by Kuhn. ${ }^{86}$ The criterion of choice is pragmatic and time-dependent.

The workability criterion of realism provides a benchmark for choosing theories and instrumental activities given the particular knowledge set of the moment of choice. It does not seem to answer the question of whether those conventions should have been adopted by the self. ${ }^{87}$ It is not a complete answer to note that liberalism's dichotomies ultimately can do no better without a leap of faith to a mysterious subjective or objective ideal whose genesis cannot be explained. Rather, the question of whether the conventions of Is are the same as the conventions of Ought seems to be the very question which led to the liberals' misconception of facts and values originally. It originates in the fallacy that criticism only takes place in statics divorced from the dynamic life process, and that therefore normative progress can only occur via a progression of static ideals or critical points. It is to mistake the requirements of description for the requirements of prescription. Comparison of statics is in itself a dynamic process. Every conscious moment is an ordering of statics. The greater the abstraction, the greater the

85. See W. JAMES, supra note 64 , at $25,38-40$; see note 64 supra.

86. Thomas Kuhn outlined a theory of scientific progress based on the periodic overthrow of past shared conventions of explanation, whose replacements integrate and expand until they in turn are overthrown. T. KuHN, supra note 62, at 6-7.

87. See R. UNGER, supra note 56, at 130-33. 
impact of our normative cognition. Hence, the real fear should be sanctification of the static, not the actual. ${ }^{88}$

But these objections sell shared valuation short, for they assume that the problem which plagues liberalism and for which liberalism can only posit a foreign and artificial solution must also inhabit the new understanding. And the premises on which it assumes the problem's applicability are liberal premises, not those of the alternative. The liberal emphasis on individualism as the basis of social organization leads to an ambiguity of content for even shared critical benchmarks. That is, a society governed by a legal system may be stable either because the norms of action are truly shared to a high degree or, momentarily, because the norms are imposed. However, when the individual's worth and dignity stem from the importance of the individual to the society and the ability to dominate others, whether through wealth, information, mystique or terror, shared valuation and understanding are only shell concepts. ${ }^{89}$

The sharing of understanding cannot be achieved by the imposition of meaning from one to another through domination. If imposed, the symbol of the interaction of individuals perceptively depends on whether one is dominating or being dominated. Values held differ from values shared..$^{90}$ It is only when the value perspective inherent within the individual's meaning becomes shared conventionalism, communicated and understood, that the understanding becomes a shared experience. The key is the genesis of the sharing of values, not the existence of "shared" values. It will only be possible to fully understand the inevitability of domination's destructiveness when the public character of language with its obvious requirement of interdependence comes to be recognized as but a minor aspect of the public character of all intercourse. Thus the sanctification of actuality, although still a real problem, exists mainly as a function of transition from liberalism toward a more social view of man. ${ }^{91}$

88. See J. Dewey, A Theory of Valuation 57-66 (1939).

89. For a related anthropological argument, see Diamond, The Rule of Law Versus the Order of Custom, in THE RULE OF LAW 115 (R. Wolff ed. 1971).

90. R. UNGER, supra note 56 , at 243.

91. Nor does such an epistemology necessarily mean the sacrifice of individual autonomy. Only the effects of autonomy-publicity of the individual's "fact-value" conventions-can be eliminated through domination. The autonomy itself can only be eliminated by ending the individual. The reason for protecting the individual then is the preservation of criticism. The justification is both historical (the advance of knowledge) and theoretical (the individual, in the usual case, never wants to live under the great risk of being dominated). The existence of the understanding itself is based on the autonomy of the choosing individual. If individual autonomy is violated, the whole scheme is to that degree impaired and the ability of all to choose is diminished. The social process is less whole.

Nor is the theory necessarily unstable. Historically, shared experience gives the shared conventions stability to the extent that stability is possible. Of course, the greater the rapidity of change within the relevant group, the greater the pluralism exhibited in convention-building, 
However, the dominant tradition creates a critical methodological problem for any alternative view of the self and society. That is, can a theory be substituted for the liberal dichotomies of reason and desire or fact and value, without mocking the historical reality of the deeply felt nature of the problem of Is and Ought? Simply plausibility by itself cannot and should not force us to shelve a traditional socio-political theory believed in and used for centuries, albeit with decreasing effectiveness. ${ }^{92}$

The remainder of this paper purports to demonstrate that Llewellyn's writings taken as a whole outline a powerful case that a beginning concept of the static-dynamic distinction had emerged in practice. It will be shown that this distinction would in turn make the use of "fact-values" the key to a new understanding of the nature of law. It remains unclear whether Llewellyn himself had reached the final stage of actually combining fact and value into "fact-values."

If people like Karl Llewellyn were able to demonstrate not only plausibility but a superior analytic methodology whose only theoretic flaw now proves an illusory misconception of critical evaluation, more is at stake than academic elegance. The question of appropriate judicial methodology can no longer turn solely on issues requiring policy deferral to the democratic legislature. The need to preserve a functioning social fabric with a shared critical faculty may require a protective screen between majority will and the longer-term aim of individual contribution to the formation of shared values. Protection of the latter ami could be provided by a judiciary which perceived the creation of that screen as its most vital task.

\section{The Radical KaRL Llewellyn}

At the foundation, Llewellyn believed that words, symbols and ideals (complex symbols) only attain meaning through the experience they symbolize. Only when experience is shared can the meaning behind the symbol be communicated. "We have discovered that rules alone, mere forms of words, are useless. We have learned that the concrete instance, the heaping up of concrete instances . . . is necessary in order to make any general proposition, be it rule of law or any other, mean anything at all."93

The first crucial step occurs when the experience which lends meaning

and the more difficult the task of harmonious sharing and interpretation of the dynamic life process as depicted by the static conventions.

92. The too obvious answers will not do: (a) that historical change must begin in speculation, (b) that the existence of a counter theory provides evidence of some historical change, and (c) that experience can easily be based on misconceptions-and frequently has been for centuries. See R. UNGER, supra note 56, at 17-18, 102-03.

93. THE BRAMBLE BUSH 12. See also A Realistic Jurisprudence 443: "[W]ords take on importance either because and insofar as they are behavior, or because and insofar as they demonstrably reflect or influence other behavior." 
is seen as dynamic while the communicable symbol remains a snapshot and static:

Every social phenomenon is ambiguous when viewed in itself. It shifts color, shape, light, meaning as you turn it. But before it can be made a datum for use in an inductive process it must first be frozen into one fixed shape. You can attempt induction only from fixed data . . . .94

At this point, it must be remembered that the symbol, man's reconstruction of the dynamic external world, remains subjective for Llewellyn. But it is not only subjective; it is value-laden as well, and value-laden as attributed by man's conventions. That is, the lawyer's natural law, resting upon "what reason can recognize in the nature of man and the life conditions of the time and place . . . in dwelling in the very circumstances of life" 95 makes value inhere in perceived "fact." From this step, the distance is short to his recognition that ascribing a "fact-value" in the actual process of convention-building is subjective criticism. Idealization is a process no different in kind from other cognition, and idealization has impact to the extent the ideal becomes shared. Idealization is the evaluation or appraising of conventionality:

[E]very normative generalization contains some quantum of idealization, of projection beyond the actual. The idealization may run only to the desirability of unchanged persistence of some particular variety of given condition; it may run to change so great that what results is empty crying in the wilderness. No matter: an ideal is set up. The second thing is that normative generalizations do not make themselves. Somebody makes them. With luck or skill, he may indeed voice just what everybody feels. Again, no matter: somebody had to voice it, before everybody could effectively feel it, for action. ${ }^{96}$

That this idealization or manipulation of experience into conventions is essential to communication was entirely explicit from the beginning: "Behavior is too heterogeneous to be dealt with except after some artificial ordering. The sense impressions which make up what we call observation are useless unless gathered into some arrangement. Nor can thought go on without categories.",97

The social significance of these "normative generalizations" (read

94. Legal Tradition and Social Science Method, supra note 23, at 109 (last emphasis in original). For a similar and sympathetic treatment of this point, consider Justice Charles Breitel's legal application: "Nevertheless, even if a pure theory of law, spun out of the manbound rational process, has the truth, it yields little more than a two-dimensional spatial relation without the color, the odor, the stuff and the historical sources of law." Breitel, Llewellyn: Realist and Rationalist, 18 RUTGERS L. REV. 745, 751 (1964).

95. The Common Law Tradition 183.

96. The Normative, the Legal, and the Law-Jobs, supra note 15, at 1362 (emphasis in original). See A Realistic Jurisprudence 450-52.

97. A Realistic Jurisprudence 453. 
complex "fact-values" or conventions) lies in their becoming widely shared. ${ }^{98}$ "They prevail. They control behavior." 99 In fact, their only significance is as shared statics, symbolizing shared experiences, normatively generalized from the process of living as a group. ${ }^{100}$ Law becomes the maintenance of the group as a shared experience. To be part of a group means participating in its shared experiences in a way that makes the concept of sharing meaningful. Thus, law embodies the accepted process of insuring the survival of the sharing function. Domination may perpetuate an agglomeration, but not a group; pluralism, from whatever source, beyond a certain acceptibly encouraged degree makes law and hence groupness (sharing) impossible. ${ }^{101}$

If Llewellyn recognized all these entailments for a "fact-value" epistemology, does it make sense to continue to attribute a traditional critical perspective to him? He summarized the theory best in arguing, "[s]ince the ultimate effectuation of a purpose is in terms of action, of behavior, the verbal formulation, to be an efficient tool, must be such as will produce the behavior desired. This turns on the relevant prevailing practices and attitudes of the relevant persons." 102

The substance of law comes from the society, of which law is itself one of the components. ${ }^{103}$ " [F]or the subject matter of its thinking it borrows the whole stock of practices, standards, ethics that make up the social, economic and religious phases of society. What is dominant in society, then, is dominant in law." 104 But this taking of the essence of society as a natural force does not sanctify actuality if one remembers Llewellyn's belief that the good inheres in the on-going process of " $[r]$ eason at work upon experience." 105 Llewellyn gave the example of the Bill of Rights, "which still have meaning . . . not because they stand in the text, but because we need some similar meaning in our lives." 106

Llewellyn argued that the dynamic normative ideal, continually being reworked in every new case and subjective as all other experiences, would

98. "[O]nce a philosophy has been established in the habits and attitudes of any person, it has effects; $a$ fortiori, if such establishment comes to prevail among a group; and again $a$ fortiori, as the group in question grows larger or more solid." Llewellyn, On Philosophy in American Law, 82 U. PA. L. REv. 205, 206 (1933).

99. The Normative, the Legal, and the Law-Jobs, supra note 15, at 1360.

100. Justice Charles Breitel has described Llewellyn's view not as a denial of precedent or standard, but as "a denial that precedent and standards can be derived from and analyzed out of a set of static universals celebrated internally, like the web spun out of a spider's belly." Breitel, supra note 94 , at 753-54 (emphasis provided).

101. See note 15 supra and accompanying text.

102. A Realistic Jurisprudence 452 (emphasis in original).

103. THE BRAmble Bush 107-08.

104. Id. at 117.

105. On the Good, the True, the Beautiful, in Law, supra note 20, at 264.

106. Llewellyn, The Constitution as an Institution, 34 CoLUM. L. REv. 1, 39 (1934). 
be better served (no matter in what form the ideal evolved) the more data of past experiences it took into account and rationalized. Further, however one defines the good, every new "fact" modifies 107 the formulation of the good by definition. A judiciary conscious of process must formulate each decision as a conduit to future experience as well as a tie to the past. ${ }^{108}$ Abstractions are grounded in experience, for there is no other place to ground them:

For when it comes to ultimate substance of the Good, I repeat that I can find no clarity, nor any conviction of reason, or of deduction as to specific matters, from the broad ultimates others have found clear. I put my faith rather, as to substance, in a means: in that on-going process of check-up and correction, which is the method and the very life of case-law . . . . " $[R]$ eason at work upon experience, to find and state explicit guidance for the future . . . ."109

In such a legal theory, the process of judicial law-making attains importance not because subjective social policy can only be legitimized in a legislative process, but because judicial law-making cannot avoid subjective social policy. Moreover, such circumstances create no cause for alarm as long as the judiciary remains sensitive to the law in society and does not diverge greatly from the group. Abdication of "situation sense" dispute resolution results in incoherence, and proves unworkable.

Admittedly, Llewellyn's vision of the static-dynamic distinction and the fact-value nondistinction never appears in so many words. There are passages seemingly impossible to reconcile. His language defimitely changed over time. Yet one should expect such difficulty given a very different dominant tradition subverting the language in another direction over centuries. And even Llewellyn's inost traditional statements leave an open door, a means for a sympathetic reader to make a plausible case.

As an example, consider part of Llewellyn's fullest methodological statement:

Science does not teach us where to go. It never will. To fuse Is and Ought is to confuse the gradually accumulating semi-permanent data on which any science must rest with the flux of changing opinion as to social objectives-that welter of objectives any of which a science can be made to serve. ${ }^{110}$

107. Modifies in the sense of affecting the probability statement regarding the truth of the formulation, although any given new fact may not actually "change" the good or fundamentally alter its perception.

108. See Twining 324-26; Corbin, The Uniform Commercial Code-Sales: Should It Be Enacted?, 59 YALE L.J. 821, 835 (1950); see also On Warranty of Quality, and Society, supra note 24; A Realistic Jurisprudence 449.

109. On the Good, the True, the Beautiful, in Law, supra note 20, at 264. See White, From Sociological Jurisprudence to Realism: Jurisprudence and Social Change in Early Twentieth Century America, 58 VA. L. REv. 999 (1972).

110. Legal Tradition and Social Science Method, supra note 23, at 101-02 (emphasis in original). 
The door-crack is "semi-permanent data." Following Kuhn, sciences rest on shared conventions (paradigms) which are used statically as springboards in dynamic investigation. Science proceeds by assuming fundamental postulates (usually justified on the basis of regular and longlasting observation) and then testing hypotheses built on the given postulates. In that sense, the Is of those symbols which are already shared as postulates is distinct from other, subjective, intended-to-be-shared static combinations of objectives or "values." In this view, Llewellyn simply attempted to keep these static concepts separate if possible. What Llewellyn did not insist upon was an abstraction-valuing knowledge different in kind from the cognition of "facts" or bits of reality."11

A somewhat earlier statement of Llewellyn's distinction appears totally ambiguous-an aim "to consistently distinguish the fact basis which will feed evaluation from the evaluation which it will later feed, to consistently seek all the relevant data one can find to add to the haphazard single-life experience, to add to general common sense." 112 Llewellyn here spoke of static fact conventions, but his evaluation was a dynamic process; he was seeking to build up the number of analyzed conventions better to understand experience. He also clearly split the evaluation process from the factual convention. That does not deny, however, that in dealing with the past fact convention, one at the same time creates a new fact-value symbol, having within one function "evaluated" by describing and prescribing the past symbol.

Part of Llewellyn's pragmatic approach lay in his stress upon continually re-analyzing past experience (by definition, an evaluation in itself). In 1960, the Common Law Tradition described a process of thinking-" "situation sense" - which Llewellyn wanted law-officials to adopt in making their decisions. For Llewellyn:

[E]xhibition of "situation-sense" involves both steps: the formulation of principles or policies and the classification of the facts into a general type-fact-situation. Indeed, it would be artificial and misleading to separate formulation of policy from classification of facts, because they are to a large extent interdependent. ${ }^{13}$

Very close to dynamic "fact-valuing."

Further evidence of Llewellyn's understanding of the operation of law can be found in the application of shared conventionality to the disputeresolution process. For Llewellyn, precedents were not abstract oughts to be applied to static facts in determining a just decision. Rather, they were a

111. But see Verdun-Jones, supra note 50, at 444.

112. Some Realism About Realism 1250. But see Llewellyn, The Theory of Legal Science, 20 N.C.L. REv. 1, $6-7$ (1941).

113. TWINING 222-23 (emphasis in original). 
fund of past conventions which allowed a slice of experience to be better understood by analogy, and therefore assisted in the dynamic process of creating a new legal convention with its own inherent norm. But, the legitimate use of these slices of reality requires that the judge understand the critical norm inhering in law-experience. ${ }^{114}$ Llewellyn would argue that this understanding demands craft: an ability to approximate through one's own cognition process the "fact-values" of the group interested in the outcome of the legal process, ${ }^{115}$ an ability to mold from the entire situation of the case a new shared convention of legally sanctioned activity aimed at either perpetuating or changing the groupness of the society. In Justice Charles Breitel's words, "[t]he situation in fact must mold the rule of law, whatever be the named goal of law-justice, equality, certainty, social mechanics, or the bare maintenance of a nonviolent order. ${ }^{116}$

A direct result of channeling dynamic experience through shared conventions (or at least shared delegation to official conventions) of past lawmaking is the lag of law behind life ${ }^{117}$ - the reason why so often the law seems to be the tool of dominant groups or a brake on social change. ${ }^{18}$ Yet, despite the strain for the legal system in a single "trouble case," the whole system usually maintains its workability. ${ }^{119}$ This problem of course intensifies as the difficulty of sharing increases. Shared values become rare as the group becomes more pluralistic in the dynamic "fact-values" it experiences

114. Harry Jones, in describing realism, turned for explication to an unlikely source-Martin Buber:

Of course there are all sorts of similarities in different situations; one can construct types of situations, one can always find to what section the particular situation belongs, and draw what is appropriate from the hoard of established maxims and habits, apply the appropriate maxim, bring into operation the appropriate habit. But what is untypical in the particular situation remains unnoticed and unanswered . . . In spite of all similarities every living situation has, like a new-born child, a new face, that has never been before and will never come again. It demands nothing of what is past. It demands presence, responsibility. . . .

Jones, supra note 29, at 802 (quoting M. BUBER, BETWEEN MAN AND MAN 113-14 (1955)).

115. Llewellyn, On Reading and Using the Newer Jurisprudence, 40 COLUM. L. REv. 581, 587-88 (1940).

116. Breitel, supra note 94 , at 747 .

117. The Relation of Certain Economic and Social Problems to the Restatement of the Law, supra note 10 , at 26.

118. "This in turn means that legal institutions-at-large act not merely to make economic specialization possible, but also as a four-wheel brake on sharp changes in the conditions and especially in the reward-distribution of specialization." The Effect of Legal Institutions Upon Economics, supra note 14 , at 668.

119. Llewellyn clearly felt and understood the paradox:

1 had to get to the Cheyennes in order to wake up to the fact that tension between form, or precedent, or other tradition and perceived need requires, in nature, to be a tension only for the single crisis. It does not have to be a continuing tension in the legal system as a whole, because an adequately resilient legal system can on occasion, or even almost regularly, absorb the particular trouble and resolve it each time into a new, usefully guiding, forward-looking felt standard-for-action or even rule-oflaw.

The Common Law Tradition 513 (emphasis provided). 
or in the static conventional representation of those fact-values that each individual communicates as his "interest" or "goals." Llewellyn applied this situation to law as follows, "[o]nce a society has become both really complex and at all mobile, a truly full integration of the legal stuff, even when one strips the 'legal' down to the bare 'official-Legal' becomes impossible." 120 There must be a lot of play in the conventions:

The doctrine at hand is always somewhat pluralistic, instinct with diverse and warring premises of growth. The unity which exists is like the unity of an organism-it is as real as is the unity of a society, that net working something which makes the society observable as a society; its unity is also of that same nature, with blurred spots and welters, with semi-disorganizations sometimes perhaps just barely held in check, but whose net balance yet yields a Whole. ${ }^{121}$

But not only must the rules have play to maintain their utility, each rule must be subdivided into sub-rules of application more tightly welded to the "fact-value" situation which spawned their meaning. Llewellyn believed that close examinations of the static facts of the case would help such a process to be more effective. ${ }^{122}$ Llewellyn himself added an additional reason for narrowing the categories of application-the failure of traditional theory adequately to adapt to changing society (another bit of evidence that Llewellyn was describing a different process and not just a different approach):

[T]hat with the new purpose in mind one approach the data afresh, taking them in as raw a condition as possible, and discovering how far and how well the available traditional categories really cover the most relevant of the raw data. And that before proceeding one undertake such modifications in the categories as may be necessary or look promising. In view of the tendency toward over-generalization in the past this is likely to mean the making of smaller categories-which may either be sub-groupings inside the received categories, or may cut across them. ${ }^{123}$

Increasingly, pluralism within the societal group has meant not simply a narrowing of decisional meaning, but a specialization of branches of regulatory law to the special needs of the individual group. "[T]he legal

120. The Normative, the Legal, and the Law-Jobs, supra note 15, at 1365.

121. Id. (emphasis in original).

122. First, if the binding legal rule is to provide an ought dictate which prescribes future judicial action, the fact situation which was an integral part of that decision must be sufficiently similar to a present situation that the same rule may be applied. Notice that such a rule assumes a rather static view of society insofar as the facts in both instances must be almost identical to provide a "just" decision. If the fact situation in a present case is materially different in any way, what was a correct ruling in the past may be completely unjust under new circumstances.

Ingersoll, Karl Llewellyn-American Legal Realism, 76 ETHICs 253, 259 (1966)(emphasis provided).

123. A Realistic Jurisprudence 453. 
feature of this age remains, not the persistence among all men of an interest in general security, but the emergence of diverse and specialized groups with a need for specialized control." 124 Development of the welfarecorporate state since this observation in 1925 offers no contradiction. There are costs to such institutionalization. But there are costs in over-generalizing the dynamic reality of law. A static law of the books which is experienced from diverse viewpoints with accordingly polar visions of the particular situation's "fact-values" will almost by defimition create a feeling of injustice whenever the overgeneralized law is applied. ${ }^{125}$ Llewellyn noted, "[t]he effects of official action must then be different, for different persons or groups, according to the interests, habits, habit-complexes, occupations; according to the type of organization, if any, of different persons in the community." 126 For the group, the law is a fragile cement.

The final piece of evidence that Llewellyn saw law as grounded in shared "fact-value" conventions appears in his view of the nature of group security. He observed that "[p]racticality, indeed, requires change as well as stability. Indeed, the very stability and security which we need in a changing society is . . . dynamic security quite as well as static." 127

In a regime of change, certainty in law is attained whenever change in the judge's ways moves in step and pace with changes in the ways-and so in the expectation - of the relevant laymen. Certainty fails for most laymen, whatever the fixity of the formula, when the judge's reactions fails to jump with the change in laymen's ways, and only then . . . . [This] goes far to explain why the law often seems fixed even in its flux, not by fiction, nor by myth, but by the pragmatic test of fulfilled expectations. ${ }^{28}$

Llewellyn meant to strengthen these pragmatic tests by investigating every decisional episode in legal life under his microscope. The "fact-value" convention he made of each "slide" became a tool for every further microenvironment. He called it "situation sense," important of itself, but related to a larger vision. "The newer Jurisprudence has as one major function to make this kind of working wisdom more explicit, ... . and so more common." 129

The liberal belief that realism is not a philosophy needs the addendum that normative philosophy is subjective; subjective in a way which can and must be shared to an extent, if groups are to remain intact; shared, because increasingly better static tools of convention-building are utilized in a

124. The Effect of Legal Institutions Upon Economics, supra note 14, at 669.

125. See Tribe, Structural Due Process, 10 HaRv. Civ. Rights-CIV. LIB. L. Rev. 269 (1975).

126. Legal Tradition and Social Science Method, supra note 23, at 94.

127. Law and the Modern Mind: I. Legal Illusion, supra note 15, at 85 .

128. Id. at 87-88.

129. On Reading and Using the Newer Jurisprudence, supra note 115, at 600. 
dynamic process of group action; such tools judged by whether the aggregate holds together in the face of mounting pressures for disintegration. Llewellyn wanted to find " a symbol for law of very different character from that of a large, cold, figure, distant, blind and carrying a sword-a symbol earth-rooted and friendly as an oak." 130

\section{CONCLUSION: In THE SHADOW}

It is suggested that what has been developed as a plausible view of the cognitive self and the process of its continual development can be generalized to the relations of groups of selves. If the aim of law is the protection of the group because the group has become essential for the development of the individual (rather than the protection of the individual in spite of and at times because of the group), value-sharing or at least norm tolerance is a necessary first step. When it becomes understood that, broadly taken, law is a contingent subsystem of the shared value structure of power-holding groups within a society, the question of legitimacy of power holding must be accounted for in any distribution of power. When it is further understood that any governmental action or inaction affects the distribution of values as it affects the prescription of not only the particular action, but all human knowledge as conventionalized by the individuals of the group, ${ }^{131}$ an inevitable impact of government on power distribution will be recognized. This includes not only the obvious direct effect on the beneficiaries (or losers) of the action, but the legitimating impact of the action as an exemplar of the possible and perhaps the preferred. Not only do "the choices we make shape the choosers we are," but the formal and informal activities that we socially allow shape the society we will become. And the society we become will have an increasing impact on the choices we have and the choosers we will be. ${ }^{132}$

The realm of values must be understood to operate on the collective level as well. Just as ends do not exist as a meaningful concept in themselves, but rather stand as symbols of an individual convention of experience, so must governmental and group purposive actions be viewed not as terminal end-states but as complex symbols taken from the context of ongoing group life.

At the governmental level, and more specifically at the level of the legal order, this implicit state of society has been operative for some time, albeit to the puzzlement of many. The inevitability of either value-sharing or value-divergence remains hidden so long as a society exists in relative

130. On the Good, the True, the Beautiful, in Law, supra note 20, at 224.

131. See J. DEWEY, supra note 88, at 57 et seq.

132. Cf. Tribe, Technology Assessment and the Fourth Discontinuity: The Limits of Instrumental Rationality, 46 S. CAL. L. REv. 617 (1973). 
historical-cultural homogeneity. Obvious distributional clashes are most likely when the growing intricacy of society combines with an accompanying opportunity for wide disparity in historical experience in the absence of a sharing orientation. So long as a society maintains relative uniformity or relatively complete domination, there probably exists sufficient value homogeneity to maintain social stability. But when technological change moves at today's speed, the lack of shared values will more clearly affect the outward manifestations of social instability via changes in the legal structure.

As man in the twentieth century finds himself more and more at odds with his fellows, and growing minorities find less and less in the current legal structure congruent with their view of the institutions and purposes of the rule of law, the traditional philosophic underpinnings which gave rise to the given ideals and structures will come under attack. They will be attacked for the same reasons the realists assailed the more obvious manifestations of the same underpinnings-rule formalism or conceptualist thought.

It has been the aim of this Article to stretch a thread of continuity from the efforts of the legal realists toward a new framework for examining and living law. A new "Social Law" demands a broader, more intensive development because the perceived defects of modern views of law lie deeper than the law itself. Because the realists dealt with the symptoms and manifestations of the coming clash of legal theories with such insight, they crucially prepared the ground for a closer examination. Karl Llewellyn and the other realists may or may not have fully realized the implications of that initial movement. It does not matter. The first step was taken, the questioning search begun. What remains undeniable is a vision of law, real and immanent, yet organic and contingent; an inherent part of an on-going life process never captured entirely by any group, scholar or historical period, always open to change without diminishing its importance or inevitability. For law, like truth, was to Llewellyn a breath, a wind, a shadow, a phantom, and we will never finish its garment. 